Prethodno priopćenje UDK 111(091)Parmenid doi: $10.21464 /$ fi36105 Primljeno 1. 12. 2015 .

\title{
Stanko Vlaški
}

Univerzitet u Novom Sadu, Filozofski fakultet, Dr Zorana Đinđića 2, RS-21000 Novi Sad

stanko.vlaski@gmail.com

\section{Parmenidovo prešućeno bogoslužje}

\begin{abstract}
Sažetak
Iako svojim učenjem o bitku nudi osnovu za prevladavanje razlike onoga ljudskog i onoga božanskog, struktura Parmenidove poeme počiva na njihovoj razlici. Problematizaciji razloga zbog kojih je elejskom filozofu bio neophodan mitsko-poetski izraz da bi iskazao uvid da sam bitak jest, autor pristupa približivši se stavu da je koherentnost Parmenidove poeme očuvana time što je ona sama mogla biti osmišljena kao najviši mogući izraz napetosti koje odlikuju ljudsko postojanje. Čovjeku je moguće misliti identitet bitka onoga božanskog $i$ onoga ljudskog, ali tu misao ne može nepomiješano učiniti elementom vlastitog svijeta. Razlika bi mogla ostati prevladanom jedino ako se o onome božanskom kao božanskom šuti.
\end{abstract}

\section{Ključne riječi}

Parmenid, poema, bitak, božansko, mythos, logos, identitet, razlika

»Religija i filozofija padaju u jedno; filozofija je zaista sama bogoslužje,ona je religija, jer ona je isto odricanje od subjektivnih zamisli i mnijenja u bavljenju bogom.«

G. W. F. Hegel ${ }^{1}$

I.

O Parmenidovoj poemi moguće je misliti kao o unikatnoj sintezi filozofije, religije i poezije. O tome postoji implicitna ili izričita suglasnost kod tumača, ali takvo suglasje izostaje kada se želi odgovoriti na pitanje zašto je takva sinteza Parmenidu bila potrebna. Filozofija je radom predstavnika tzv. jonske škole, kao i djelatnošću pitagorejaca, već stekla mogućnost za odlučniju emancipaciju svoje pojmovnosti od tradiranih stilova mišljenja poput onoga mitotvorno-pjesničkog. Nije preuveličana ocjena da to što se neki od najvećih mislilaca, čak i nakon etabliranja »filozofske proze«, vraćaju poeziji kao posredniku objavljivanja svoje filozofske poruke, predstavlja »jedan od najtežih skandala rane grčke filozofije«.2

Georg Wilhelm Friedrich Hegel, Predavanja o filozofiji religije I, Naklada Breza, Zagreb 2009., str. 35.

2

Glenn W. Most, »The Poetics of Early Greek Philosophy«, u: Anthony A. Long (ur.), The
Cambridge Companion to Early Greek Philosophy, Cambridge University Press, Cambridge 1999., str. 332-362, doi: http://dx.doi. org/10.1017/CCOL0521441226.016, str. 350. 
Parmenid je bio prvi koji je učešće u tom »skandalu« uzeo posvetivši život filozofiji. Zašto je on svoj put $\mathrm{k}$ saznanju onoga što jest prikazao u mitskom ruhu kao put religijskog posvećenja? Zašto je tajnovitoj boginji prepustio da svojom pričom otkrije tajnu razlike putova istinskog saznanja i mnijenja?

Pokušaj da se smisao ovih pitanja sagleda u svojoj izoliranosti od rezultata brojnih interpretacija ne može biti plodotvoran. Debate o smislu Parmenidovog povratka mitotvornom izrazu elementi su smisla tog događaja sâmog i on ne postoji nezavisno od njih. Interpretatorske alternative koje, doduše, nisu isključujuće, ali koje se tijekom dva i pol tisućljeća čitanja Elejčeve poeme opiru svođenju jedne na drugu, mogu se razlučiti s obzirom na svoje postavljanje prema alegorici Parmenidovog djela. S jedne strane, niz tumača nudi argumente u prilog stavu da je Parmenidu mitsko-poetski obrazac bio potreban prije svega da bi se filozofski sukus poeme mogao lakše obznaniti onima koji još nisu stasali za pojmovno mišljenje. Mitsko zaodijevanje filozofskog sadržaja tako ima didaktičku svrhu i Parmenid mu svjesno pristupa. ${ }^{3} \mathrm{Na}$ tragu Hegelove kritičke valorizacije zavodljivog veličanja mitskih aspekata Platonove filozofije, kao onoga što u njoj ima najveću vrijednost, može se i sâmom Parmenidu spočitati nedovoljna izbrušenost pojmovnog mišljenja:

»Tko u simbole skriva misli taj nema misli. Misao je ono što sebe očituje, otuda mit nije adekvatan posrednik za misao. $\ll^{4}$

Usprkos ponekad gorljivom inzistiranju suvremenih komentatora na distanci u odnosu na hegelijansko shvaćanje antičke filozofije, dvije ovako ocrtane putanje tumačenja imaju isto ishodište: filozofski, znanstveni novum iz centralnog dijela Parmenidove poeme sasvim je očišćen primjesa mitskog mišljenja, što mythos potiskuje na margine kao nešto što nema značajnijih implikacija po Parmenidov znanstveni rezultat. ${ }^{5}$

S druge strane, nisu manje utjecajni ni tumači koji su bliži stavu da mitskopoetska forma jest imanentni činilac onoga što je Parmenida, u pogledu filozofskog sadržaja, učinilo epohalnim misliocem. Karl Reinhardt, na primjer, napominje da je »mitološka odora « cjeline poeme »daleko više od alegorije« i da je ona nešto »u cijelosti i temeljno drugačije od prazne poze ili ustupka poetskoj ugodi «, ${ }^{6}$ a Werner Jaeger ističe da je Parmenid, daleko od blijede alegorije, preuzeo »religijsku formu izražavanja i prenio je u sferu filozofije«. Za Jaegera, Elejčeva »misteriozna vizija u carstvu svjetlosti« je »istinsko religijsko iskustvo «, ${ }^{7}$ dok i u recentnim interpretacijama ima mjesta za tezu da je kod Parmenida na djelu »metodološka zavisnost o božanskoj pomoći«. ${ }^{8}$ Takva tumačenja u stanju su integrirati misaona dobra alegorijskih čitanja te o Parmenidu, uz izvjestan oprez, govoriti $i$ kao o religioznom misliocu onoga mističnog.

Interpretatorski odnos prema mitsko-poetskom elementu Parmenidove filozofske poeme u krajnjoj liniji zavisi od načina poimanja sâme filozofije i njene povijesti. Kako je prvo tematsko polaganje računa o odnosu pojma $f i$ lozofije prema njenoj vlastitoj povijesti rezultat rada filozofa koje se danas najčešće obuhvaća sintagmom »njemački klasični idealizam«, novije diskusije o razumijevanju ključnih antičkih filozofskih učenja često se implicite ili eksplicitno zatiču u dijalogu s idealističkim misaonim motivima. Jedan takav motiv nalazi se kod Friedricha Wilhelma Josepha Schellinga koji piše o potrebi povratka filozofije $\mathrm{u}$ »opći ocean« iz koga je proistekla, $\mathrm{u}$ ocean poezije. Takav povratak za njega znači jedino moguće ozbiljenje filozofije, ali on više ne može biti neposredan. Put kojim ljudski rod može krenuti k izgubljenom jedinstvu duha ocrtava mitologija: 
»Što će, pak, biti srednji član povratka znanosti k poeziji, to u općenitosti nije teško reći, jer je takav srednji član egzistirao u mitologiji, prije nego što se, kao što se to sada čini, dogodilo to nerazrješivo rastavljanje. $\ll^{9}$

Hegelovo zrelo poimanje filozofije i njene povijesti karakterizirano je programskom delegitimizacijom ideje nove mitologije kao tobožnjeg sredstva ozbiljenja filozofskog pojma. ${ }^{10}$ Povijesna snaga mitologije je okopnila samo zbog toga što su njene temeljne intencije ostvarene radom drugih, viših formi duhovnosti. Pokušaj modernog oblikovanja filozofije spram kalupa platonovskih mitova nasilje je nad ljudskim duhom zbog kojega je Hegel prinuđen izreći spominjanu pokudu novih filozofskih mitotvorstava. Ipak, nju se ne može bezrezervno primijeniti pri tumačenju Parmenidove poeme. Poemu elejskog filozofa, kao umjetnički oblik, Hegel razmatra u svojim Predavanjima o estetici, ${ }^{11}$ a mitski proemij u svojem predavanju o Parmenidu, s kursa o povijesti filozofije, naziva veličanstvenim zato što nam pokazuje »maniru

Među dosljednijim zastupnicima takvog stanovišta je Cecil Maurice Bowra. On alegorici poeme prilazi uvjeren da Parmenid (prije svega u prologu) »očito alegorizira«, ali da se alegorija slama u momentu kada pjesnik dolazi »do svog stvarnog zadatka«, tako da čitalac, i pored činjenice da Parmenid traganje za istinom osjeća kao svojevrsnu religioznu aktivnost, može biti sasvim siguran da Parmenid »ne daje literarni zapis duhovne avanture «, već da »svoje traganje za istinom zaodijeva u alegorijsku odjeću« (Cecil Maurice Bowra, » The Proem of Parmenides«, Classical Philology, god. 32 (2/1937), str. 97-112, doi: http:// dx.doi.org/10.1086/362001, str. 98).

4

Georg Vilhelm Fridrih Hegel [Georg Wilhelm Friedrich Hegel], Istorija filozofije I, BIGZ, Beograd 1975., str. 75-76.

John E. Boodin tako, primjerice, ponavlja veliko pitanje je li Parmenid bio pjesnik i komentira: »Komentatori su učinili jasnim to da ga ne smatraju pjesnikom, nego suhim logičarem. Ali zašto se on onda izražava poezijom i heksametrom, svečanim stilom epskih pjesnika? Ne može se reći da je za filozofe-znanstvenike bilo moderno koristiti poeziju.« (John E. Boodin, »The Vision of Parmenides «, The Philosophical Review, god. 52 (6/1943), str. 578-589, doi: http://dx.doi. org/10.2307/2181260, str. 578) Potaknut istraživanjima Johna Burneta, Boodin će ponuditi objašnjenje kojim je pitanje, u izvjesnoj mjeri, trivijalizirano jer će Parmenidov pjesnički izraz protumačiti kao prosto očitovanje (rekli bismo arhimedovskog) oduševljenja znanstvenim otkrićima do kojih je došao.

Karl Reinhardt, » The Relation Between the Two Parts of Parmenides' Poem«, u: Alexander P. D. Mourelatos (ur.), The Pre-Socratics. A Collection of Critical Essays, Anchor Press,
Doubleday, Garden City, New York 1974., str. 301 .

7

Prema Verner Jeger [Werner Jaeger], Teologija ranih grčkih filozofa, Službeni glasnik, Beograd 2007., str. 86. Na sličnom tragu je i Vlastos kada utvrđuje da je kod Parmenida i Empedokla »čitavo učenje o Bitku i Prirodi izneseno kao religijsko otkrivenje« (Gregory Vlastos, »Theology and Philosophy in Early Greek Thought«, The Philosophical Quarterly, god. 2 (7/1952), str. 97-123, doi: http:// dx.doi.org/10.2307/2216899, str. 97).

8

Sarah Broadie, »Rational Theology«, u: Anthony A. Long (ur.), The Cambridge Companion to Early Greek Philosophy, str. 205224, doi: http://dx.doi.org/10.1017/CCOL05 21441226.010, str. 208.

Friedrich Wilhelm Joseph Schelling, Sistem transcendentalnog idealizma, Naprijed, Zagreb 1965., str. 272.

10

U tzv. »Najstarijem programu sistema njemačkog idealizma«, iz 1796./1797. godine, Schelling, Hölderlin i Hegel po svoj prilici zajednički plediraju za »jednu novu mitologiju« - mitologiju uma: »Mitologija mora postati filozofska, narod uman, a filozofija mora postati mitološka, da bi filozofa učinila čulnim « (Georg Wilhelm Friedrich Hegel, „Najstariji program sistema njemačkog idealizma«, u: Georg Wilhelm Friedrich Hegel, Rani spisi, Veselin Masleša, Sarajevo 1982., str. 178).

11

Vidi Georg Vilhelm Fridrih Hegel [Georg Wilhelm Friedrich Hegel], Estetika III, Kultura, Beograd 1970., str. 446. 
vremena i u cjelini jednu energičnu, plahovitu dušu koja se hrva sa sućinom da bi je shvatila i izrazila. « ${ }^{12}$ Njemački filozof isto tako naglašava da poezija i mit za stare i za modernog čovjeka ne znače isto:

»Kod starih mitova mit ne predstavlja samo omot; nije čovjek naprosto imao misao pa ju je samo sakrio. To se može dogoditi na naš reflektirajući način; ali iskonska poezija ne polazi od izdvajanja proze i poezije. $\ll^{13}$

Bez obzira na to što stanje nediferenciranosti ljudskog duha nema isto značenje u Hegelovom i Schellingovom poimanju filozofije, čini se da istraživanje odnosa mythosa i logosa u Parmenidovoj poemi uvijek već polazi putanjom uvida ovih filozofa. Ono se kreće stazom pitanja: je li filozofija od Parmenidovog doba u neprilici da, posredstvom mitskih slika, povremeno osmišljava povratak u vlastiti izvor koji je totalitet aktivnosti duha i nerazličnost poezije, religije i znanosti, ili Parmenid još uvijek misli njihovo izvorno jedinstvo $i z$ jedinstva samog?

Ta pitanost zahtijeva osvrt na ono što za Parmenida znači misliti.

\section{II.}

Mišljenje kod Parmenida još ne postavlja sebe sâmo, kao što je to slučaj u učenjima modernih filozofa, ali nije lako ponuditi konzistentnu argumentaciju u prilog stava da je kod grčkog filozofa na djelu određivanje mišljenja prirodom predmeta kojem ono nastoji odgovarati. Po svojoj sućini, obje opcije su rezultat tog istog, modernističkog čitanja Parmenidove poeme. Problematičnost primjene okoštalog okvira za interpretaciju, koji svaku antičku ontologiju mjeri kao objektivističku, dâ se utvrditi istraživanjem misaonih motiva središnjeg djela Elejčeve poeme.

Parmenid tu prepušta riječ tajanstvenoj boginji, koja na prešućena pitanja o tome što jest istinski predmet mišljenja i po čemu istinito mišljenje jest istinito, nudi zapanjujuće sveden odgovor: istinski se može misliti samo - da jest (hōs éstin). Što jest jest je sâmo. Bitak (tò ón/eón) jest to jest. Jedini put koji je moguće istražiti jest »da jest i kako ne može ne biti«. ${ }^{14}$ Nebitak (mè eón) nije misliv i nije istraživ kao nebitak zato što se zamišljanjem istovremeno preobražava u nešto. ${ }^{15}$ Kako se kod Elejaca još ne pojavljuje govor o bitku kao bitku (tò einai), tako parmenidovsko biće ne može biti protumačeno ni kao s bitkom sâmim nepoistovjetivo, pojedinačno biće. ${ }^{16}$ Tò ón Parmenid misli izvornije u odnosu na takvu diferenciju. Ono je naprosto jedno (hen) i neprekidno (synechés). ${ }^{17}$ Njemu se ne može pristupiti onako kako se inače saznaje nešto pojedinačno jer određenje što ono pojedinačno jest istovremeno je tvrdnja da ono nije nešto drugo, to jest da nije ono što nije. Mišljenje pojedinačnog ne može odvesti k istinskoj spoznaji jer ni ono što ono misli istinski nije, nego je iluzorna mješavina bitka i nebitka. Bitak, čija je bit samo da jest, nema »što nije«. Što bitak nije, naprosto nije ništa. Ništa nije mislivo, niti izrecivo:

$»$ Mora se zboriti i misliti da bitak postoji, jer biti jest, a ništa nije. $«^{18}$

Nikakvog drugog mišljenja (noein) ni kazivanja (legein) nema osim mišljenja i iskazivanja bitka ${ }^{19}$ koje, kao sâmo jest, jest jedno i nepodijeljeno. Jednost bitka prekoračuje svaku pojedinačnost. Hegel ovaj Parmenidov stav približava spinozističkom geslu po kojem je svako određenje negacija (Omnis determinatio negatio est). Bliskost Parmenidove i Spinozine filozofske pozici- 
je potom je bivala predmetom sporadičnog interesa komentatora, premda o nepobitnom značaju principa koji je etabliran Parmenidovom poemom ništa manje uvjerljivo ne svjedoče riječi Johana Gottlieba Fichtea, kao filozofa koji se svojim filozofskim stavom deklarirao kao beskompromisna oprečnost elejskom filozofskom principu. Pri objašnjenju načela svojega »učenja o znanosti« Fichte bilježi:

»Apsolutni Ja prvog načela nije nešto (on nema predikata i ne može ga imati), on je naprosto ono što jest, a to se ne da dalje razjasniti [...]. Apsolutnome Ja suprotstavljen [...] jest Ne-ja naprosto ništa. $\ll^{20}$

Sužavaju li ipak predikati bitka iz prvih deset stihova VIII. fragmenta - po kojima ono jest nestvoreno, nepropadljivo, cijelo, jednorodno, nepokretno i ne-bez-dovršenja ${ }^{21}$ - polje važenja Parmenidovog filozofskog principa? Za elejskog filozofa je karakteristično to što ta određenja nemaju odredbeni karakter kakav imaju predikati u sudu. Bitak ne bi trebalo shvatiti kao subjekt

12

G. W. F. Hegel, Istorija filozofije I, str. 214

13

Ibid. Isti je smisao Reinhardtove kritike teza o »mitološkoj odori« poeme kao posljedici Parmenidove kalkulantske alegorije: »Strogo govoreći, tu nema nikakve 'odore', jer tu nema ničeg što bi prvo bilo formulirano apstraktno, a čemu bi potom bila dana artificijelna fizička, ako i prozirna, odjeća.« (K. Reinhardt, »The Relation between the Two Parts of Parmenides' Poem«, str. 301)

14

Parmenid iz Eleje, »O prirodi«, u: Slobodan Žunjić (ur.), Fragmenti elejaca: Parmenid - Zenon - Melis, BIGZ, Beograd 1984., str. 68 , fr. II, stih 3-4.

15

G. W. F. Hegel, Istorija filozofije I, str. 215

16

U ovome slijedimo sugestiju Slobodana Žunjića: »Elejci još ne upotrebljavaju termin oùsia ili tò einai da bi izrazili ono što Nijemci nazivaju das Sein, Francuzi L'Etre, a Englezi Being [...]. Ta riječ [tò ón ili eón - op.a.], ustvari, označava nešto manje od bivstvovanja (Sein), ali svakako nešto više od bivstvujućeg (das Seiende) u modernom semantičkom razgraničenju tih ontoloških termina.« (Slobodan Žunjić, »Elejska teorija bića«, str. 15) Značaj stupnjevanja u označavanju, kojim suvremeno doba nastoji oslušnuti odjek helenskog izvornika, ovdje, dakako, ne smije biti precijenjen jer Parmenidova misao opoziva samu mogućnost stupnjevanja tò ón o kojem je ovdje riječ.

17

Parmenid, »O prirodi«, str. 69, fr. VIII, stih 6. Usporedi s Parmenides, Lehrgedicht: Griechisch und Deutsch von Hermann Diels, Druck und Verlag von Georg Reimer, Berlin 1897., str. 36
18

Ibid., str. 68, fr. VI, stih 1-2.

19

Guthrie sugerira da noein za Grke uopće nije mišljenje, nego »akt neposrednog prepoznavanja (recognition)« nečega postojećeg, kao i to da u svijetu Stare Helade nije bilo neuobičajeno reći da netko »(ne) misli ništa« ili da »(ne) govori ništa《: »(Ne) reći ništa na grčkom ne znači šutjeti: to je normalan izraz za pričanje besmislica, izgovaranje onoga što ne korespondira s realnošću.« (William Keith Chambers Guthrie, A History of Greek Philosophy II (The Presocratic Tradition from Parmenides to Democritus), Cambridge University Press, Cambridge 1969., str. 17-18)

20

Johann Gottlieb Fichte, Osnova cjelokupne nauke o znanosti, Naprijed, Zagreb 1974., str. 58-59.

21

Prevodilačka se rješenja sasvim razilaze $u$ pogledu statusa grčkog izvornika ed(e) ateleston. Iz Dielsovog čitanja slijedi da je bitak »bez završetka (ohne Ende)《 (Parmenides, Lehrgedicht, str. 37), a identično je i Burnetovo "without end" (John Burnet, Early Greek Philosophy, Adam and Charles Black, London 1908., str. 199). Poricanje ograničenosti bitka oponira Aristotelovom razlikovanju Parmenidovog i Melisovog filozofskog stanovišta jer Stagiranin kaže da je Parmenid govorio o jednom kao o ograničenom, dok je Melis jedno nazivao neograničenim (Aristotel, Metafizika, Globus, Liber, Zagreb 1988. 986b20-22, str. 19-20). Stava smo da tu ograničenost treba shvatiti upravo aristotelovski, odnosno prema pojmu, a ne prema tvari, iako će naše dalje izlaganje pokušati pokazati da parmenidovska pojmovnost općenito prevladava distinkciju pojma i tvari. 
koji se »raspada« na predikate! »Odredbe« su za Parmenida shemata, kao znamenja ili znaci bitka sâmog i njegovo prisustvovanje u mišljenju. ${ }^{22} \mathrm{Kao}$ što se jest kod Parmenida istovremeno upotrebljava u svom kopulativnom i u svom egzistencijalnom značenju, ${ }^{23}$ znamenja bitka su, kao predikati sudova, načini na koji jest (= bitak), jest i među njima nema niti sukcesije, niti odnosa subordinacije. Označavanje bitka u mišljenju nije proces u kojem se očituje primat mišljenja, kao što nema mjesta ni za prioritet bitka jer je kod Parmenida izvršena ontološka delegitimizacija procesualnosti i sukcesije uopće. Mišljenje i bitak nisu na način diferencije! Ono što jest kroz diferenciju spram nečeg drugog za Parmenida zapravo - nije. Bitak i mišljenje istovjetno jesu. Bez ikakvog posredovanja »isto se može misliti i biti ${ }^{24}$ i boginji elejskog filozofa, kako slijedi iz V. fragmenta, svejedno je od kojeg će početi jer će se vratiti na isto.

Bitak nije nešto pojedinačno, kao što uopće nije nešto jer vlastitom odredbom ne biva razgraničeno od nečeg drugog (onog što ono nije) i na taj način ograničeno njime, premda se ljudsko iskustvo formira upravo na takav način. Mora se primijetiti da ono čulno pojedinačno nije istinska granica bitka i da je bitak ograničen samo sobom, iako je uobičajeno misliti da postoji nekakav dualitet općosti bitka i čulne pojedinačnosti. Takav dualizam ne postoji jer samo jest jest. Boginja odvraća Parmenida od dualističkog načina mišljenja kao od puta istraživanja

»... na kome smrtnici bez ikakva znanja zapliću dvostrukom glavom, jer smutnja u njihovim grudima zanoseći um goni«,

te su tako

»... nošeni tamo-amo jednako gluhi i slijepi, zbunjeni; nerazborita krda, kojima je shvaćanje da biti i ne-biti jest isto i nije isto, i za koje je povratan put staza svega«. ${ }^{25}$

Taj put je put iskustva, a Elejac treba suditi logosom. Bitak jest samo za logos, kao što i logos misli i kazuje samo da jest i ništa drugo jer ništa osim bitka nije. Između bitka i logosa ne postoji nijedna od mogućih varijacija subjektobjekt odnosa zato što misliti i govoriti za Parmenida znači misliti i izgovarati bitak, kao što i bitak jest bitak mišljenja:

»Isto je što se da misliti i ono radi čega je misao. Jer bez bića za koje je misao vezana, ti nećeš naći razabiranje, jer nigdje nema niti će biti nečeg drugog osim bića. $\ll^{26}$

Mutatis mutandis, ograničen je domašaj raspravljanja o »idealizmu« ili »materijalizmu« Parmenidove poeme. Ta je rasprava vrijedna samo utoliko što je u njoj vječito vrelo interesa za Elejčevo djelo. U novijem dobu ona je rasplamsana prije svega provokativnom Burnetovom tezom o Parmenidu kao »ocu materijalizma«, do koje ovaj ugledni istraživač helenske misli dolazi promišljajući oznake parmenidovskog bitka:

»Ono što jest, jest konačna, sferična, nepokretna, tjelesna punina (plenum) i ne postoji ništa izvan toga. Pojave mnoštva i kretanja, praznog prostora i vremena predstavljaju iluzije.«

Već je Melis to ispravno shvatio i on se zbog toga za Burneta pojavljuje kao »stvarni sistematičar elejskog učenja«. ${ }^{27}$ Odgovarajući na silne prigovore zastupnika Parmenidovog »idealizma«, Burnet u predgovoru trećem izdanju svoje utjecajne Rane grčke filozofije svoju tezu brani na način koji je čini donekle izlišnom:

»'Materija', kako je ja shvaćam, za materijaliste uopće nije objekt čula, ona je isto toliko koliko i duh, ili više, ens rationis i Parmenidov 'bitak' je prvi jasan pokušaj da se shvati ta nečulna stvarnost. $\ll^{28}$ 
Ostaje zagonetno što točno Burnet ima u vidu kada napominje da svojom tezom oponira »hegelovskom stanovištu « u razmatranju stvari predsokratske filozofije. Baš povodom aristotelovskog komentara (Met. 986b20) o Melisovoj »materijalističkoj« razradi Parmenidove doktrine, Hegel priopćava:

»... upravo u čistoj sućini, bitku [Sein - op. a.], jednome, ova razlika otpada; za Parmenida i za Melisa ne postoje ni čista materija ni čista misao, već su one ukinute. I samo bi u načinu njihovog izražavanja morao ležati razlog iz kojeg bi moglo izgledati da je sućinu jedan shvatio više tako. «29

Bitak ne dopušta ni da ga se dovodi u vezu s »najvišim bićem «. Na putu istine ono se ne naziva - kao kod Ksenofana - bogom, niti onim božanskim jer jest ne dopušta stupnjevanje. Ono ne zna za podjelu na božansko i ljudsko, njega nema negdje više, a negdje pak manje (fr. VIII.). Može li se taj zaključak zaoštriti tako što bi se reklo da je i sâma razlika božanskog i ne-božanskog samo imenovanje, kojim se sućinski ne zahvaća ništa, već se miješaju bitak i nebitak? U blizini takvog zaključka moguća je potpuna problematizacija strukture Parmenidove poeme, ali i pitanosti od koje je pošlo naše izlaganje: Kako, naime, shvatiti da tajnovita boginja, u heksametarskom stihu koji je važio za karakterističnu formu mitskog, odnosno religioznog kazivanja starih Grka, Parmenidu kazuje mythos o putu kako jest, pritom ga osvjetljavajući znamenjima koja su i mitotvorno pjesništvo i ranije filozofsko mišljenje prepoznavali kao božansko, ali istovremeno propuštajući da ih izrijekom pripiše nečemu što bi se zvalo bogom ili božanskim? ${ }^{30}$ Je li ostala ikakva mogućnost mislive koegzistencije stava o bitku i mitotvoračkog bogoslužja?

22

Slična prevodilačka i interpretativna rješenja zastupaju Diels (shemata $=$ njem. Merkpfähle znaci, odlike) i Burnet (shemata = eng. tokens: simboli, znaci, značke, uspomene). Anthony Preus termin shema objašnjava kao formu, oblik, pojavu, tj. kao riječ kojom se imenuje karakteristična osobina nečeg (Anthony Preus, Historical Dictionary of Ancient Greek Philosophy, The Scarecrow Press, Maryland, Toronto, Plymouth 2007., str. 233).

23

Theodor Gomperz, Greek Thinkers. A History of Ancient Philosophy I, John Murray, London 1901., str. 173. Srodno i kod Žunjića u »Elejska teorija bića«, str. 17.

24

Parmenid, »O prirodi«, str. 68, fr. III. Škiljanov prijevod ovog čuvenog fragmenta glasi: »... jer isto je misliti (kao) i biti« (Hermann Diels, Predsokratovci. Fragmenti I, Naprijed, Zagreb 1983., str. 208, B3), dok Sandra Šćepanović, na osnovi Burnetovog prevodilačkog rješenja, čita: »Jedno je, naime, isto: ono što misliti možeš i ono što može biti« (Džon Barnet [John Burnet], Rana grčka filozofija, ZUNS, Beograd 2004., str. 210).

25

Parmenid, »O prirodi «, str. 68, fr. VI, stih 5-10. Na ovom mjestu možemo samo u obrisima prikazati polove velike rasprave koja se vodi o tome upućuje li Parmenid stihom o »povratnom putu« na sadržaj Heraklitovog 60. fragmenta (»Put prema gore i prema dolje je jedan i isti«, prema H. Diels, Predsokratovci. Fragmenti I, str. 154, B60). Burnet, primjerice, uz svu suzdržanost, ističe da se finale šestog fragmenta »teško može razumjeti kao bilo što drugo osim kao Heraklitov put 'nagore i nadolje' (J. Burnet, Rana grčka filozofija, str. 217). S druge je strane npr. Reinhardt: »Gdje bismo mi to kod Heraklita mogli pronaći bilo kakav nagovještaj učenja po kome bitak i ne-bitak nisu isto? Činjenica je da kod Parmenida niti jedna jedina riječ ne referira ni na što strano, ne-elejsko.« (K. Reinhardt, "The Relation between the Two Parts of Parmenides' Poem«, str. 301).

26

Parmenid, »O prirodi«, str. 70, fr. VIII., stih 34-35.

27

J. Burnet, Rana grčka filozofija, str. 219, 387. 28

Ibid., str. 8 .

29

G. W. F. Hegel, Istorija filozofije I, str. 220 [istaknuo autor]. Čini se da se i spornom pitanju o loptastom obliku parmenidovskog bitka, o kojem govori 42. stih VIII. fragmenta poeme, može pristupiti bez modernističkog razdvajanja »čiste materije« $\mathrm{i}$ »čiste misli«.

30

Više tumača skreće pažnju na tu činjenicu: Jaeger zapisuje da Parmenid, poput starijih mi- 


\section{III.}

Mistični put k boginji koja će ga uputiti dalje, u istinu, Parmenid prelazi uz pomoć božanskih bića i to putovanje opisuje u prologu svoje poeme. Premda je svaki njegov stih inicirao zasebne filozofske i filološke polemike, na ovom mjestu možemo pokušati misliti Parmenidovo putovanje s obzirom na njegovo odredište. Negativni moment tog rezultata može se razumjeti kao podrivanje temelja dualističkog stila mišljenja. Iako dualističko mišljenje kod Grka nije moglo poprimiti razmjere moderne subjekt-objekt opreke, Parmenid je naslutio da »mnijenja smrtnika« razdvajaju (dvòje) opće i pojedinačno, božansko i ljudsko, ono što jest i ono što nije, i da samim razdvajanjem beznadno miješaju prirodu stvari. Helenski filozof, dakako, to ne izražava modernim pojmom uzajamnog uvjetovanja. On je još u stanju misliti slikom. Koje je Parmenidovo objedinjeno ime za ta dvojenja, saznajemo iz boginjinog kazivanja s početka drugog dijela poeme. Da Elejca ne bi preteklo »mišljenje kog smrtnika«, boginja pripovijeda kako izgleda »sve uređenje svijeta«. Prema toj priči, zastranjivanje smrtnika odigralo se činom suprotstavljanja vatre $i$ noć $i$ :

»... oprekama razlučiše oba lika i znamenja namjestiše odvojeno jedne od drugih; ovdje, nebeski plam ognja, koji je blag i veoma lak, sebi samom svuda isti ali ne istovjetan s drugim; a drugi je po sebi baš opreka, mračna noć, pojava gustog i teškog.«11

Gornji navod mogao bi prokrčiti put k napomeni koja je od presudnog značaja za čitanje Parmenidove poeme: osnova pogrešnosti ljudskih mnijenja nije u tome što se vatri-svjetlu bespotrebno suprotstavila noć, čime se relativizirao značaj i moć svijetlog principa. Mnijenja su u svojoj osnovi lažna zato što se ne mogu riješiti potrebe da u temelj svega postave nešto pojedinačno u njegovoj čulnoj određenosti. Ta određenost istovremeno je granica njegovog bića. Ono jest nešto $i$ nije nešto drugo! Biti i ne-biti su i isto i različito, baš kao što je nebeska svjetlost ognja (kao, uostalom, i voda i zrak jonskih kozmologa) uvijek jednaka sa sobom, ali i neistovjetna s onim ne-svijetlim i kao takva ne može izraziti bitak, koji je jedno. ${ }^{32}$

Parmenid mora prevladati vlastitu smrtnu, čulnu prirodu - kako nam govori prvi fragment, on mora poći »preko svih gradova«, »od staze ljudi daleko« - da bi koraknuo putom istine. No moći kojima on sam kao čovjek raspolaže, po svemu sudeći, nisu bile dovoljne za stupanje na taj put.

Religiozna mistika prologa, koju neki interpretatori dovode u vezu s orfičkim kultom (npr. Burnet, Jaeger), a neki je približavaju čak starim šamanističkim elementima (Guthrie), donosi, s jedne strane, potenciranje ličnog karaktera Parmenidovog duhovnog iskustva, ${ }^{33}$ dok se, s druge strane, ne saznaje mnogo o Parmenidovom osobnom aktivitetu na ovom putovanju. Kobile koje ga nose mogu predstavljati nerazumsku stranu duše, a predvodeće djevice mogu predstavljati čula, kao što je Parmenid »Sunčevim kćerima« mogao nazvati vlastite oči - kako to tumači Sekst Empirik (DK B1) - ali ni takva interpretacija ne može poštedjeti postavljanja pitanja o razlogu zbog kojeg Parmenid izrijekom relativizira vlastitu ulogu u opisu nečega što bi moglo biti osobno religijsko iskustvo. ${ }^{34}$

Značajna debata i danas se vodi oko objašnjenja smjera u kojem se kreću Parmenidove božanske kočije. U tumačenju, u dominantnoj verziji riječ je o nebeskom usponu u carstvo svjetlosti, ali svoje zagovornike imaju i čitanja po kojima je zapravo riječ o Parmenidovom orfejskom silasku u donji svijet i u tamu noći, koje se nastavlja korakom u istinsku svjetlost ${ }^{35}$ ili o putu ka »kući Noći« u kojoj biva suspendirana funkcija čula. ${ }^{36} \mathrm{~S}$ obzirom da boginja završava svoj mythos o putu istine osvjetljavajući put mnijenja tragom njegovog 
polazišta o dualizmu vatre i tame, ne čini se da pravo Parmenidovo ishodište može značiti finalnu favorizaciju jednog ili drugog principa. Stvari su urušene već time što uopće postoje dva principa! S druge strane, ostaje mogućnost da se i dan/svjetlost i noć/tama shvate kao oličenja principa mišljenja kojim se misli da jest i da se na taj način udalje od svog primarnog, čulnog smisla. No u tom slučaju nikakve sućinske diferencije između njih ne bi bilo. Možda je to Platon mogao izraziti svojom slavnom »alegorijom pećine«: u čistoj svjetlosti umskog saznanja izbavljenik iz pećine ne vidi ništa od onoga što neuki smatraju stvarnim. On ne vidi ništa određeno (predmete čulnog opažanja), ${ }^{37}$ baš kao što to ne bi mogao ni u potpunom mraku. ${ }^{38} \mathrm{Za}$ saznanje empirijski "stvarnog « nužna je pomiješanost svjetlosti i tame. Takvo saznanje, u svom odnošenju na nastajanje i propadanje, na ono što jest i ono što nije, za Platona je mnijenje (doxa), dok se noesis odnosi na bivstvo (oùsia) stvari (Pol. 534a), to jest na ono što stvar jest - na njeno bezvremeno i nečulno sućstvo.

Čitanjem drugog dijela Parmenidove poeme, saznajemo da je i za ovog filozofa, odnosno za boginju koja mu se obraća, u mnijenjima smrtnika sve »ujedno ispunjeno i svjetlom i nejavnom tamom«, a da je takav i sam njihov um. ${ }^{39}$ Parmenid je radikalniji utoliko što ljudskim mnijenjima ne nalazi mjesto u poretku bitka jer u jednom ne može biti nikakvog »poretka« elemenata. Važno je

slilaca, znanje o postojećem »povezuje sa sferom religije«, to čini »s osobitim uspjehom«, ali isto tako »nesumnjivo propušta izjednačiti bitak s bogom, mada su u kasnijim vremenima njegovu teoriju o apsolutnom biću i njegovim predikatima iznova izgrađivali kao filozofsku teologiju « (W. Jaeger, Teologija ranih grčkih filozofa, str. 94). Burnet podvlači kao »upadljivo« to što Parmenid »izbjegava termin 'bog', koji su raniji i kasniji mislioci slobodno koristili« (J. Burnet, Rana grčka filozofija, str. 216). Broadie naglašava isti fakt $\mathrm{i}$ utvrđuje da je već u antici Parmenidov bitak poistovjećivan $\mathrm{s}$ Ksenofanovim najvećim bogom (S. Broadie, »Rational Theology«, str. 214).

31

Parmenid, »O prirodi «, str. 70, fr. VIII., stih 55-60.

32

Usporedi Reinhardtov komentar: »Greška tog svjetonazora je u stavljanju dvije forme umjesto jedne, ali to nipošto ne znači reći da će jedna od dvije, npr. svjetlo, biti bliža istinskoj realnosti u odnosu na tamu.« (K. Reinhardt, »The Relation between the Two Parts of Parmenides' Poem «, str. 304)

33

Uvjerljivo o tome govori Jaeger: »Prvi put u grčkom, filozofskom jeziku susrećemo filozofsku ličnost koja se smatra nosiocem znanja.«(W. Jaeger, Teologija ranih grčkih filozofa, str. 87) Ta pojava, prema Jaegeru, Parmenida čini bližim Hesiodu negoli homerovskoj skromnosti.

34

Pitanje ostaje važeće i ako se u obzir uzme još preciznije tumačenje porijekla slika prologa Parmenidove poeme, poput onog koje oblikuje Bowra. On tako metafizičke kočije, kojima se odvozi Parmenid, prepoznaje kao čestu sliku VI. i V. stoljeća prije naše ere $i$ pronalazi njene varijetete kod Simonida, Empedokla, Euripida i Pindara; motiv vrata pred koja Parmenid stiže uspoređuje sa sadržajima Hesiodove Teogonije i utvrđuje koji su motivi slike podudarni s Heraklovim putem na Olimp, pričom o Helijevom sinu Faetontu itd. Bowra istraživanje zaključuje stavom da Parmenid preuzima "prihvaćene fraze i daje im novo značenje u novom kontekstu, ali sama činjenica da ih on preuzima pokazuje da on svoj put istine smatra usporedivim, ali i, po svoj prilici, superiornim u odnosu na putove religijskih sekti« (C. M. Bowra, »The Proem of Parmenides«, str. 110).

35

Usp. Francis M. Cornford, From Religion to Philosophy. A Study in the Origins of Western Speculation, Harper and Brothers Publishers, New York 1957., str. 214-215.

36

To zastupa npr. David Sedley (David Sedley, »Parmenides and Melissus«, u: A. A. Long (ur.), The Cambridge Companion to Early Greek Philosophy, str. 113-133, doi: http:// dx.doi.org/10.1017/CCOL0521441226.006, str. 114, 122).

37

Prema napomeni Branka Pavlovića uz tekst sedme knjige Platonove Države (usp. Platon, Država, BIGZ, Beograd 1976., str. 371).

38 Platon, Država, str. 207, 516a1-5.

39

Parmenid, »O prirodi«, str. 69, fr. IX. i XVI. 
zapaziti da se i putovanje iz proemija odvija kroz oblast pomiješanosti svjetla i noći, a ne kroz apsolutnu tamu jer se svjetlost miješa s tamom zahvaljujući »plamtećoj osovini« kočija koje voze Parmenida. Tu mješavinu simboliziraju »Helija kćeri« ${ }^{40}$ Vrata putova Noći i Dana otvara »mnogomučna« (polypoi$n o s)^{41}$ Pravda i omogućuje Parmenidu da od boginje čuje priču o putu istine i putu mnijenja. Iako se na osnovu te slike može tražiti zaključak o težnji za istinom koja je sama po sebi etička aktivnost, kao što to čini Bowra, ${ }^{42}$ u samoj istini ostaje malo prostora za etičku aktivnost zato što u njoj nikakvog aktiviteta nema, niti bilo čega što pripada sferi ljudskog praksisa. ${ }^{43}$ Parmenidovski bitak, prema osmom fragmentu poeme, jest bez potreba, pa zbog toga ne treba biti dobro ili ne-dobro. Ono nije u mogućnosti biti dobro ili ne-dobro samo zbog toga što nije $u$ mogućnosti, već jest samo jest, koje je jedno. Takav uvid može imati relativističke konzekvence po pozicije ljudskih znanja i normi djelovanja, tako da se s Reinhardtom može govoriti da Parmenid priprema tlo za sofističku relativističku problematizaciju odnosa onoga što je po prirodi i onoga što je po zakonu (physis - nomos) ${ }^{44}$ Ipak, nikakvog relativizma kod Parmenida principijelno ne može biti jer je tu delegitimizirano svako mišljenje koje počiva na relaciji. Bitak se ne da izraziti kao referentni okvir za ljudske partikularitete. Ljudske djelatne norme ne mogu se mjeriti u odnosu spram bitka jer ono ne dopušta da ga se shvati kao dio relacije s bilo čime, osim sa sobom samim! Uspjelost Parmenidovog učenja o bitku zavisi i od uspjeha u namjeri da ga se razriješi odnosa prema aristokratskim, demokratskim i uopće svim poznatim pojedinačnim političkim formama. ${ }^{45}$

Ista je Parmenidova namjera i u pogledu prevladavanja tradicionalnih oblika religijskih ustrojstava učenjem o bitku. Ono zaista

»... signalizira da je Put istine poduhvat veoma različit od svih tradicionalnih razmatranja božanskih stvari«. ${ }^{46}$

Kao što se iluzornim može pokazati sofistički intonirano geslo »sve je istina« ili »sve je opravdano« - jer za Parmenida sve nije, već jest samo jedno, jest - teško je nadovezati se na Cornfordovo pitanje koje pretpostavlja da je kod elejskog filozofa bitak isto što i bog i da je riječ o panteizmu:

»Ako je bog u sebi savršen, zašto bi on ikada napustio to stanje i istupio u nestvarnost i nesavršenost? $\ll^{47}$

Parmenidovski bitak je okovan sobom i sebe uopće ne napušta, naprosto zbog toga što jest. ${ }^{48} \mathrm{Na}$ istom tragu se može slijediti Hegelova interpretacija Parmenidove poeme u svom osporavanju legitimnosti samorazumljivog kvalificiranja Elejčeve misli kao panteističke. Panteistička identifikacija svega postojećeg i boga (»Hen kai Pan«) nalazi svoju granicu u Parmenidovom principu. Elejac, prema Hegelu, kaže da »bitak [das Sein] je sve [ne obratno! - op. a.]«. Čini se, doduše, da je to panteizam, ali »ta misao je čišća [...] i nije panteizam《 jer on »izričito kaže: jest samo bitak [das Sein], a u nebitak [das Nichtsein] pada sva granica, sva realnost, svi načini egzistencije; i to uopće nije nego samo ima bitak [es hat nur das Sein] «. ${ }^{49}$

Provokativna je i Cornfordova teza o parmenidovskom bogu »koji napušta svijet«, ali isključivo ako se ne shvati na način judeo-kršćanske predstave o ugroženosti saveza transcendentnog Boga i čovjeka, ali ni u maniru modernih teza o »raščaravanju« svijeta. Moglo bi se reći da bog napušta svijet utoliko što svijet, kao poprište ljudskih borbi za prevlast nad partikularnostima, istinski nije, ${ }^{50}$ već se nudi kao iluzorna mješavina pojedinačnosti i općosti, negacije i afirmacije. Onda ostaje postavit i pitanje ostaje li u poemi ikakvog načina da bog jest. 


\section{IV.}

Parmenidov put dešava se s onu stranu određenosti ljudskog svijeta, iznad svake pojedinačnosti. Prolog poeme inzistira na osobnom karakteru njegovog duhovnog iskustva, ali pribjegavanje metaforici božanskih pomoćnika na tom putu slabi personalnu notu izlaganja. Takav potez ne mora samo značiti sačuvanu dozu autorske skromnosti nadahnutog pjesnika koji je, inače, svoju osobnost već sagledao kao privilegiranu. Ne mora se on isključiv pravdati ni

40

Usp. Gregory Vlastos, »Parmenides' Theory of Knowledge«, Transactions and Proceedings of the American Philological Association, god. 77 (1946), str. 66-77, str. 73.

41

Parmenid, »O prirodi«, str. 67, fr. I., stih 14. Prijevod S. Šćepanović Pravdu vidi kao onu »što kažnjava strogo« (J. Burnet, Rana grčka filozofija, str. 208), dok je kod D. Škiljana Dike »s kaznama mnogim« (H. Diels, Predsokratovci. Fragmenti I, str. 207, B1.14).

42

»Etički karakter Dike pokazan je epitetom polypoinos koji joj je pridat.« Bowra smatra da je tu riječ o orfičarskom (»Orfički pogled bio je naprosto takav da Dike nagrađuje dobro i kažnjava zlo. Parmenid proširuje pojam nagrade i kazne na sferu istine i pogrešnosti $)$ i hesiodovskom elementu poeme (C. M. Bowra, »The Proem of Parmenides «, str. 107-108). S. Žunjić, pak, u komentaru poeme napominje da je Pravda na ovom mjestu, anaksimandrovski, osjetljiva na povredu kozmičkog reda prije nego na povredu moralnog poretka o kojem govori Hesiod (S. Žunjić (ur.), Fragmenti elejaca, str. 95).

43

Željko Kaluđerović, Presokratsko razumevanje pravde, Izdavačka knjižarnica Zorana Stojanovića, Sremski Karlovci, Novi Sad 2013. str. 209.

44

K. Reinhardt, »The Relation between the Two Parts of Parmenides' Poem«, str. 311. O opreci physis-nomos i njenom mjestu u rađanju moralnog fenomena detaljnije u: Milenko A. Perović, Etika, Grafomedia, Novi Sad 2001. str. 125-127.

45

Minar, pak, raspravlja s Vlastosovim tezama o demokratizatorskom potencijalu Parmenidovog učenja uz pomoć tvrdnji koje potkrepljuje malobrojnim poznatim detaljima Elejčeve biografije. Aristokratsko Parmenidovo porijeklo i njegovu vjerojatnu bliskost s pitagorejskim duhovnim krugovima Minar dovodi u vezu s učenjem o bitku. Parmenidovo mukotrpno oponiranje ideji promjene za ovog tumača je indikator filozofovog stava prema društvenim problemima. Minar će time dovršiti portret
Parmenida kao konzervativnog aristokrata (Edwin L. Minar, Jr., »Parmenides and the World of Seeming «, The American Journal of Philology, god. 70 (1/1949), str. 41-55, doi: http://dx.doi.org/10.2307/290964).

46

S. Broadie, »Rational Theology«, str. 214. 47

F. M. Cornford, From Religion to Philosophy, str. 216

48

To dosta podsjeća na kasniju Schellingovu opasku upućenu osporavaocima filozofije apsolutnog identiteta: »Temeljna zabluda sve filozofije jest pretpostavka da je apsolutni identitet zbiljski istupio iz sebe, i nastojanje da se ovo istupanje, na ma koji način, učini pojmljivim.« (Friedrich Wilhelm Joseph Schelling, »Prikaz mojega sistema filozofije«, u: Friedrich Wilhelm Joseph Schelling, O bitstvu slobode, CEKADE, Zagreb 1985., par. 14, str. 80-81) Schellingovom komentaru moglo bi se dodati to da je postojao mislilac koji je to spoznao mnogo prije Spinoze - Parmenid.

49

G. W. F. Hegel, Predavanja o filozofiji religije I, str. 249-250; usp. Georg Wilhelm Friedrich Hegel, Vorlesungen über die Philosophie der Religion I, Werke XVI, Suhrkamp Verlag, Frankfurt am Main 1986., str. 317. Nije zgoreg dodati da u Znanosti logike Hegel još uvijek govori da elejska misao o identitetu upravo jest sućina apstraktnog panteizma (Georg Vilhelm Fridrih Hegel [Georg Wilhelm Friedrich Hegel], Nauka logike I, BIGZ, Beograd 1987., str. 88). Poistovjećenje parmenidovskog tò ón i neposrednosti Seina kojim Logika počinje svoj će odjek pronaći i u navedenim riječima iz Filozofije religije. 50

Milan Kangrga naglašava da je pojam svijeta povijesno i smisaono povezan s pojmom svijesti $\gg$ kojom je postavljeno i mišljeno ono unutrašnje razdvajanje (Trennung) na subjekt i objekt« (Milan Kangrga, Praksa - vrijemesvijet. Iskušavanje mišljenja revolucije, Nolit, Beograd 1984., str. 479) - helenski kozmos još ne izražava takvo razdvajanje! 
didaktičkom svrhom pjesničke djelatnosti, koja bi trebala biti namijenjena širem krugu ljudi. Taj pjesnički postupak bi istovremeno mogao značiti i postepenu depersonalizaciju sadržaja poeme. Počast ukazana pojedincu nije sama sebi cilj, ali će se pokazati da takav karakter nema ni služba bogova grčkog svijeta. Apsolutna depersonalizacija mišljenja ne može se postići postepenim napredovanjem. Ona zahtijeva $s k o k^{51}$ iz pomiješanosti regije pojavnog koju kočije proemija još nisu napustile. Poništenje načina na koji smrtnici određuju stvari i negiranje personalizacije puta $\mathrm{k}$ istini nije dosegnuto ni u trenu kada Parmenid mythos prepušta bezimenoj boginji, mada je služba istini na koju nagovara boginja, u usporedbi s dotadašnjim načinima ukazivanja počasti bogovima, za slušaoca ili čitaoca svakako mogla biti nešto uzvišeno.

Boginjin mythos otkriva logos koji obezvređuje takve komparacije jer saznanje da jedino jest jest, a da ono što nije - nije ništa - točka je indiferencije mita i logosa. Kazivanje (mythos) jest način prisustvovanja onoga kazanog (bića) u logosu, i to bića kao logosa. Kazivanje pjesnika kazivanje je boginje, a time se odlazi izvan sfere domašaja pitanja o prioritetu onoga božanskog ili onoga ljudskog. Potpuna depersonalizacija, kao negiranje prostorno-vremenske određenosti, ne postiže se, prema tome, tako što Parmenid, kao smrtnik (iako privilegirani!), umanjuje svoje učešće u saznanju istine i njega prepušta misterioznoj boginji čija je personalnost nešto što je za njega, kao smrtnika, uzvišeno. To se postiže time što boginja propušta da govori o bitku kao o nečem božanskom i time odustaje od vlastite biti!

$\mathrm{O}$ čemu je pobliže riječ?

Identitet bogova kao bogova, identitet smrtnika kao određenih pojedinaca, kao i razlika onoga što pripada božanskom i onoga što pripada ljudskom, postoji samo na putu mnijenja. Na njemu se »isto« i »ne-isto« pojavljuju i kao isti i kao različiti. Boginjin mythos smrtniku Parmenidu otkriva da bogovi i ljudi isto jesu jer je jest jedno. Ono je i božansko i ljudsko. Ovakvo tumačenje nema niti kršćanski, niti panteistički smisao jer značenje identifikacije boga i čovjeka biva iscrpljeno u tome što ona negira temelj njihove egzistencije kao određenih entiteta. Osmi fragment upućuje na to da bi te određenosti mogle biti samo imenovanja od strane smrtnika.

U mišljenju bitka prevladana je razlika božanskog i ljudskog. Što jest na način razlike od nečeg drugog, istinski nije. U tom je mišljenju prešućeno ono božansko $i$ to je jedini način kako ono može biti. U mišljenju nema razlikovanja, nema mješavine mnijenja i to mišljenje, koje se očituje znamenjima onoga božanskog, prešućeno je bogoslužje. ${ }^{52}$ Prestankom važenja razlike počinje filozofija i to kao bogoslužje. Na takav pojam filozofije je Hegel mogao misliti kada je obznanio da je »pravo filozofiranje« kao »uzdizanje u carstvo idealnog « započelo s Parmenidom. ${ }^{53}$ Takvo filozofiranje ne postavlja sebe niti nasuprot, niti paralelno s drugim manifestacijama duha, kakve su religija i umjetnost, nego sobom donosi ostvarenje najdublje intencije umjetnosti i religije - poistovjećenje čovjeka i onoga božanskog. To više poistovjećenje nije moguće reflektirati s pozicija tradicionalne religioznosti ili umjetničkog stvaralaštva, pa tako ni sa stanovišta mitotvornog pjesništva ili kozmologije kakvu su poznavali Grci. S tih stajališnih točaka započeto »pravo filozofiranje« nosi princip koji je destruktivan po njihov status i zbog toga ga se nastoji držati na izvjesnoj distanci, pa se utvrđuje razlika religioznog pjesništva, kozmologije i filozofske znanosti. Ipak, za čovjeka kao takvog čisto mišljenje tek je eksces u sveopćoj izmiješanosti njegove egzistencije. Čovjek obično ne govori samo da jest, već istovremeno govori što je i što nije. To je priroda njegovog mišljenja i kazivanja. ${ }^{54}$ Njegovo mišljenje samo izuzetno misli 
biće, koje je biće mišljenja. ${ }^{55} \mathrm{U}$ momentu napuštanja »staza ljudi«, ali i staza tradicionalne religije, čovjekovo mišljenje misli identitet s onim što »ima« božanska znamenja, ali u trenutku kada bi ga se pokušalo osloviti bogom ili physisom, taj bi se identitet ukinuo i čovjek bi se »povratnim putem« vratio modusima saznanja tradicionalne religije ili filozofske kozmologije kao zasebnim tipovima duhovnosti. Mitotvorna »odora« skriva istinu utoliko što je svako kazivanje, koje pokušava kazati nešto drugo osim da jest, sućinski skrivajuće. Umjetničko oblikovanje tu ne nastupa kao artificijelni dodatak.

Parmenidova poema kao cjelina izražava tu napetost. Ona donosi kazivanje o mišljenju kojim se nadilazi razlika onoga božanskog i onoga ljudskog upravo kroz ustrajavanje u njihovoj međusobnoj razlici. Ono ljudsko i ono božansko jesu tu kako isto, tako i različito. Ako se izbjegava izmirenje s takvim ishodom kao nužnim momentom kretanja filozofskog mišljenja, dosljedno je samo ne govoriti ništa.

\title{
Stanko Vlaški
}

\section{Parmenides' Unspoken Worship of God}

\begin{abstract}
Although Parmenides' doctrine of Being offers a reason for overcoming the difference between the human and the divine, structure of his poem lies in this difference. The author approaches the reasons for why Eleatic philosopher needed mythos and verses to express his insight that only Being is by coming close to the thesis that coherence of Parmenides' poem has been preserved by the possibility that it was conceived as the highest expression of the tensions characterizing human existence. Any human can think identity of being as human and divine, but this thought he cannot make part of his world. The difference could continue to be overcome only by keeping silence about the divine as divine.
\end{abstract}

\section{Keywords}

Parmenides, poem, Being, divine, mythos, logos, identity, difference

51

Allan H. Coxon je jedan od tumača koji svojevrsno otkrivenje vidi kao jedini način prijelaza iz fizičkog svijeta $\mathrm{u}$ istinu. $\mathrm{O}$ tome u Allan H. Coxon, » The Philosophy of Parmenides «, The Classical Quarterly, god. 28 (3-4/1934), str. 134-144, doi: http://dx.doi. org/10.1017/s0009838800019960.

52

Srodna je tome i Jaegerova zamisao o Parmenidovoj misteriji bića.

53

G. W. F. Hegel, Istorija filozofije I, str. 216.

54

To Heidegger, uz pohvalu Reinhardtovom objašnjenju strukture Parmenidove poeme komentira riječima: »Da boginja istine, koja vodi Parmenida, njega stavlja pred dva puta
- put otkrivanja i put prikrivanja, ne znači ništa drugo nego da je tubitak svagda već u istini i neistini.« (Martin Hajdeger [Martin Heidegger], Bitak $i$ vreme, Službeni glasnik, Beograd 2007., str. 263).

55

Umjesna je onda analogija s Aristotelovim pojmom boga koju izvodi Branko Bošnjak: »Aristotelov bog nalik je na Parmenidov bitak [...]. I Aristotelov bog kao i Parmenidov bitak postaje nešto što je samo sebi dovoljno. Bog je na kraju ipak najveći filozof, on je mišljenje mišljenja, i svijet niti stvara niti se njime hoće baviti. Time je bog postao ideal razuma, a nije predmet ispoljavanja srca.« (Branko Bošnjak, Grčka filozofska kritika Biblije. Kelsos contra apologeticos, Naprijed, Zagreb 1971., str. 45). 